\title{
Development and the Role of Tissue Culture in Plant Breeding:
}

\section{A review}

\author{
Sisay Argaye* \\ Ethiopian Institutes of Agricultural Research, Holetta Agricultural Research Center, Ethiopia
}

*Corresponding Authors: Sisay Argaye, Ethiopian Institutes of Agricultural Research, Holetta Agricultural Research Center, Ethiopia

\begin{abstract}
Crop production is negatively impacted by numerous biotic and abiotic stresses. Discovering the underlying genes affecting important traits such as yield, quality, disease resistance, and climate adaptability is of par-amount importance to increase the agricultural productivity and to mitigate production and productivity limiting biotic and abiotic stress. Conventional plant breeding can occur through a variety of approaches and for a number of objectives, including participatory plant breeding, improving seeds through hybridization. Hybridization, the deliberate cross of two genetically different plants from two separate plant populations, tends to create varieties that mature earlier, produce higher yields and greater uniformity. However, Plant tissue culture have extended the range of crop species from which haploid plants have been produced as well as the efficiency resulting in large-scale haploid plant production by anther and microspore culture techniques. Specialized plant tissue culture methods have enabled the production of completely homozygous breeding lines from gametic cells in a shortened time frame compared to conventional plant breeding. The main objective of this paper is to review the development and the role of tissue culture in plant breeding. Tissue culture is the in vitro aseptic culture of cells, tissues, organs or whole plant under controlled nutritional and environmental conditions often to produce the clones of plants. The tissue culture technique has been applicable in plant breeding; provides the means of genetic transformation, somatic embryogenesis and organogenesis, embryo rescue, haploid production, double haploid production, cell suspension culture, in production of virus free plant, protoplast fusion in producing the desired hybrids, Somaclonal variation to the creation of additional genetic variability, micro propagation, production of synthetic seed and cryopreserved for future use for germplasm conservation. In general, plant tissue culture represents the most promising areas of application at present time and giving an out look into the future.
\end{abstract}

Keywords: Breeding, Cells, Organs, Plant, Tissue culture

\section{INTRODUCTION}

In the globe, a rapidly growing population is increasing food demand whilst resources such as good quality land, water and soil are becoming scarcer. Crop production is negatively impacted by numerous biotic and abiotic stresses. As fertilizers such as phosphorous and nitrogen become increasingly scarce and expensive, developing plant varieties that can withstand climate variability, lower rainfalls, warmer temperatures, fewer inputs and pest and disease outbreaks is increasingly vital. Plants that use resources more efficiently or require fewer resources altogether improve the sustainability of agricultural as well as urban and forest ecosystems. Discovering the underlying genes affecting important traits such as yield, quality, disease resistance, and climate adaptability is of paramount importance to increase the agricultural productivity and to feed the world's growing population it is needed to mitigate production and productivity limiting biotic and abiotic stress.

Plant breeding is the process of selecting plants with the most desirable qualities to produce offspring that inherit these desired traits. It aims to develop improved crop cultivars crops selected for desirable characteristics that can be reproduced to satisfy a variety of needs and overcome a multitude of challenges. Insect and disease resistant cultivars are often highly desirable, if not essential, especially where pesticides are ineffective or restricted. Breeders also seek to produce crop varieties that appeal to consumer taste, satisfy cooking preferences, adhere to food safety regulations, enhance nutritional quality or behave best when used for industrial applications. The application of genetics in crop improvement has yielded many successes leading to unprecedented growth in agricultural productivity, spurred by government commitments to agricultural research and development and supporting sectors. 
Conventional plant breeding can occur through a variety of approaches and for a number of objectives, including participatory plant breeding, improving seeds through hybridization or enhancing their nutritional properties with bio fortification. Rather than employing a 'top-down' model whereby seed varieties are improved by professional breeders and then made available to farmers, participatory plant breeding involves farmers in the various stages and decision-making milestones during the breeding process. Hybridization, the deliberate cross of two genetically different plants from two separate plant populations, tends to create varieties that mature earlier, produce higher yields and greater uniformity. However, Plant tissue culture have extended the range of crop species from which haploid plants have been produced as well as the efficiency resulting in large-scale haploid plant production by anther and microspore culture techniques. Specialized plant tissue culture methods have enabled the production of completely homozygous breeding lines from gametic cells in a shortened time frame compared to conventional plant breeding. The main objective of this paper is to review the development and the role of tissue culture in plant breeding.

Tissue culture is the in vitro aseptic culture of cells, tissues, organs or whole plant under controlled nutritional and environmental conditions often to produce the clones of plants. The resultant clones are true-to type of the selected genotype. The controlled conditions provide the culture an environment conducive for their growth and multiplication. These conditions include proper supply of nutrients, $\mathrm{pH}$ medium, adequate temperature and proper gaseous and liquid environment.

Plant tissue culture technology is being widely used for large scale plant multiplication. Apart from their use as a tool of research, plant tissue culture techniques have in recent years, become of major industrial importance in the area of plant propagation, disease elimination, plant improvement and production of secondary metabolites and small pieces of tissue can be used to produce hundreds and thousands of plants in a continuous process. A single explant can be multiplied into several thousand plants in relatively short time period and space under controlled conditions, irrespective of the season and weather on a year round basis (AkinIdowu et al., 2009). Endangered, threatened and rare species have successfully been grown and conserved by micro propagation because of high coefficient of multiplication and small demands on number of initial plants and space.

In addition, plant tissue culture is considered to be the most efficient technology for crop improvement by the production of somaclonal and gametoclonal variants. The micro propagation technology has a vast potential to produce plants of superior quality, isolation of useful variants in well-adapted high yielding genotypes with better disease resistance and stress tolerance capacities (Brown and Thorpe, 1995). Certain type of callus cultures give rise to clones that have inheritable characteristics different from those of parent plants due to the possibility of occurrence of somaclonal variability which leads to the development of commercially important improved varieties (George, 1993).

\section{Historical Development Of Plant Tissue Culture}

The science of plant tissue culture takes its roots from the discovery of cell followed by propounding of cell theory. In 1838, Schleiden and Schwann proposed that cell is the basic structural unit of all living organisms. They visualized that cell is capable of autonomy and therefore it should be possible for each cell if given an environment to regenerate into whole plant. Based on this premise, in 1902, a German physiologist, Gottlieb Haberlandt for the first time attempted to culture isolated single palisade cells from leaves in knop's salt solution enriched with sucrose. The cells remained alive for up to one month, increased in size, accumulated starch but failed to divide. Though he was unsuccessful but laid down the foundation of tissue culture technology for which he is regarded as the father of plant tissue culture. After that some of the landmark discoveries took place in tissue culture which are summarized as:

In 1934, White was the first who successfully established the culture of tomato roots in an artificial nutrient medium, thus achieving the first organ culture. In this work, tomato root tips could grow independently in the laboratory. Later, scientists defined the chemical signals that allow plant tissues in culture to differentiate (to form callus of parenchyma cells) and then dedifferentiate to form embryo and plantlets. While in 1939, Gautheret and Nobecaust succeeded in making callus culture using cambial tissue.

Morel and Martin in 1952 succeeded to free plants from virus infection by culturing and regenerating plants from meristems. After a year, Skoog and Miller in 1953, noted that the importance of Auxin 
and cytokinin ratio in different forms of plant tissue culture. Then after in 1960, Cocking started the protoplast isolation and culturing. Consequently, Murashige and Skoog in 1962 devised a culture medium for tobacco; it has served as the starting point for the development of a defined growth medium for many species. Interestingly, in 1967 Bourgin and Nitsch succeeded in the production of haploid plants by anther culture of Nicotiana. On the same crop, in 1972 Carlson and his co-workers succeeded in the production of somatic cell hybrids by fusing protoplasts of the two Nicotiana species. Nowadays, its application becomes useful in genetic engineering.

\section{Current And Future Status Of Plant Tissue Culture}

The past decades of plant cell biotechnology has evolved as a new era in the field of biotechnology, focusing on the production of a large number of secondary plant products. During the second half of the last century the development of genetic engineering and molecular biology techniques allowed the appearance of improved and new agricultural products which have occupied an increasing demand in the productive systems of several countries worldwide (Navarro and Mastache, 2007). Nevertheless, these would have been impossible without the development of tissue culture techniques, which provided the tools for the introduction of genetic information into plant cells (Pareek, 2005). Nowadays, one of the most promising methods of producing proteins and other medicinal substances, such as antibodies and vaccines, is the use of transgenic plants (Ferrante and Simpson, 2001). Transgenic plants represent an economical alternative to fermentation-based production systems. Plant-made vaccines or antibodies are especially striking, as plants are free of human diseases, thus reducing screening costs for viruses and bacterial toxins. The number of farmers who have incorporated transgenic plants into their production systems in 2008 was 13.3 million, in comparison to 11 million in 2007 (James, 2008).

\section{The Role Of Tissue Culture In Plant Breeding}

\section{Genetic transformation}

Genetic transformation is the most recent aspect of plant cell and tissue culture that provides the mean of transfer of genes with desirable trait into host plants and recovery of transgenic plants (Hinchee et al., 1994). The technique has a great potential of genetic improvement of various crop plants by integrating in plant biotechnology and breeding programmes. It has a promising role for the introduction of agronomically important traits such as increased yield, better quality and enhanced resistance to pests and diseases (Sinclair et al., 2004).

Genetic transformation in plants can be achieved by either vector-mediated (indirect gene transfer) or vectorless (direct gene transfer) method (Sasson, 1993). Among vector dependant gene transfer methods, Agro bacterium-mediated genetic transformation is most widely used for the expression of foreign genes in plant cells. Successful introduction of agronomic traits in plants was achieved by using root explants for the genetic transformation. Virus-based vectors offers an alternative way of stable and rapid transient protein expression in plant cells thus providing an efficient mean of recombinant protein production on large scale (Chung et al., 2006).

Recently successful transgenic plants of Jatropha were obtained by direct DNA delivery to mature seed-derived shoot apices via particle bombardment method (Purkayastha et al., 2002). This technology has an important impact on the reduction of toxic substances in seeds. Thus overcoming the obstacle of seed utilization in various industrial sectors. Regeneration of disease or viral resistant plants is now achieved by employing genetic transformation technique. Researchers succeeded in developing transgenic plants of potato resistant to potato virus $\mathrm{Y}$ which is a major threat to potato crop worldwide (Bukovinszki et al., 2007). In addition, marker free transgenic plants of Petunia hybrids were produced using multi-auto-transformation vector system. The plants exhibited high level of resistance to Botrytis cinerea causal agent of gray mold (Khan et al., 2011).

\section{Embryo culture}

Embryo culture is a type of plant tissue culture that is used to grow embryos from seeds and ovules in a nutrient medium. In embryo culture, the plant develops directly from the embryo or indirectly through the formation of callus and then subsequent formation of shoots and roots. The technique has been developed to break seed dormancy, test the vitality of seeds, production of rare species and haploid plants (Holeman, 2009). It is an effective technique that is employed to shorten the breeding cycle of plants by growing excised embryos and results in the reduction of long dormancy period of 
seeds. Intra-varietal hybrids of an economically important energy plant "Jatropha" have been produced successfully with the specific objective of mass multiplication (Mohan et al., 2011). Somatic embryogenesis and plant regeneration has been carried out in embryo cultures of Jucara Palm for rapid cloning and improvement of selected individuals (Guerra and Handro, 1988). In addition, conservation of endangered species can also be attained by practicing embryo culture technique. Recently a successful protocol has been developed for the in vitro propagation of Khayagrandifoliola by excising embryos from mature seeds (Okere and Adegey, 2011). The plant has a high economic value for timber wood and for medicinal purposes as well. This technique has an important application in forestry by offering a mean of propagation of elite individuals where the selection and improvement of natural population is difficult.

\section{Somatic embryogenesis and organogenesis}

Somatic embryogenesis: is an in vitro method of plant regeneration widely used as an important biotechnological tool for sustained clonal propagation (Park et al., 1998). It is a process by which somatic cells or tissues develop into differentiated embryos. These somatic embryos can develop into whole plants without undergoing the process of sexual fertilization as done by zygotic embryos. The somatic embryogenesis can be initiated directly from the explants or indirectly by the establishment of mass of unorganized cells named callus. Plant regeneration via somatic embryogenesis occurs by the induction of embryogenic cultures from zygotic seed, leaf or stem segment and further multiplication of embryos. Mature embryos are then cultured for germination and plantlet development, and finally transferred to soil

Somatic embryogenesis has been reported in many plants including trees and ornamental plants of different families. The phenomenon has been observed in some cactus species. There are various factors that affect the induction and development of somatic embryos in cultured cells. A highly efficient protocol has been reported by Jayasankar et al. (1999) for somatic embryogenesis on grapevine that showed higher plant regeneration sufficiently when the tissues were cultured in liquid medium. Plant growth regulators play an important role in the regeneration and proliferation of somatic embryos. Highest efficiency of embryonic callus was induced by culturing nodal stem segments of rose hybrids on medium supplemented with various PGR's alone or in combination (Xiangqian et al., 2002). This embryonic callus showed high germination rate of somatic embryos when grown on abscisic acid alone. Somatic embryogenesis is not only a process of regenerating the plants for mass propagation but also regarded as a valuable tool for genetic manipulation. The process can also be used to develop the plants that are resistant to various kinds of stresses and to introduce the genes by genetic transformation (Maynard et al., 1998; Bouquet and Terregrosa, 2003). A successful protocol has been developed for regeneration of cotton cultivars with resistance to Fusarium and Verticillium wilts (Han et al ., 2009).

Organogenesis: refers to the production of plant organs i.e. roots, shoots and leaves that may arise directly from the meristems or indirectly from the undifferentiated cell masses (callus). Plant regeneration via organogenesis involves the callus production and differentiation of adventitious meristems into organs by altering the concentration of plant growth hormones in nutrient medium. Skoog and Muller were the first who demonstrated that high ratio of cytokinin to auxin stimulated the formation of shoots in tobacco callus while high auxin to cytokinin ratio induced root regeneration.

\section{Embryo rescue}

Embryo rescue is one of the earliest and successful forms of in-vitro culture techniques that is used to assist in the development of plant embryos that might not survive to become viable plants (Sage et al., 2010). Embryo rescue plays an important role in modern plant breeding, allowing the development of many interspecific and intergeneric food and ornamental plant crop hybrids. This technique nurtures the immature or weak embryo, thus allowing it the chance to survive. Plant embryos are multicellular structures that have the potential to develop into a new plant. The most widely used embryo rescue procedure is referred to as embryo culture, and involves excising plant embryos and placing them onto media culture (Miyajuma, 2006). Embryo rescue is most often used to create interspecific and intergeneric crosses that would normally produce seeds which are aborted. Interspecific incompatibility in plants can occur for many reasons, but most often embryo abortion occurs (Reed and Sandra, 2005). In plant breeding, wide hybridization crosses can result in small shrunken seeds which indicate that fertilization has occurred, however the seed fails to develop. Many times, remote 
hybridizations will fail to undergo normal sexual reproduction, thus embryo rescue can assist to overcame this problem (Bridgen and Mark, 1994).

\section{Haploid production}

The tissue culture techniques enable to produce homozygous plants in relatively short time period through the protoplast, anther and microspore cultures instead of conventional breeding (Morrison and Evans, 1998).

Haploids are sterile plants having single set of chromosomes which are converted into homozygous diploids by spontaneous or induced chromosome doubling. The doubling of chromosomes restores the fertility of plants resulting in production of double haploids with potential to become pure breeding new cultivars (Basu et al., 2011). The term androgenesis refers to the production of haploid plants from young pollen cells without undergoing fertilization. Sudherson et al. (2008) reported haploid plant production of sturt's desert pea by using pollen grains as primary explants. The haploidy technology has now become an integral part of plant breeding programs by speeding up the production of inbred lines and overcoming the constraints of seed dormancy and embryo non-viability (Yeung et al., 1981; Bajaj, 1990). The technique has a remarkable use in genetic transformation by the production of haploid plants with induced resistance to various biotic and abiotic stresses. Introduction of genes with desired trait at haploid state followed by chromosome doubling led to the production of double haploids inbred wheat and drought tolerant plants were attained successfully (Chauhan and Khurana, 2011).

\section{Doubled haploids}

The production of doubled haploids is an importance advance in wheat breeding, because the duration of breeding programmers is reduced. In addition, due to complete homozygosity of doubled haploid lines, the identification of superior genotypes is easier. The aims of doubled haploids culture in plant breeding as; releasing new varieties through F1 double-haploid System, selection of mutants resistant to disease, developing asexual lines of trees/perennial Species and transfer of desired alien genes.

\section{Cell suspension culture}

Cell suspension culture systems are used nowadays for large scale culturing of plant cells from which secondary metabolites could be extracted. A suspension culture is developed by transferring the relatively friable portion of the callus into liquid medium and is maintained under suitable conditions of aeration, agitation, light, temperature and other physical parameters (Chattopadhyay et al., 2002). Cell cultures cannot only yield defined standard phyto chemicals in large volumes but also eliminate the presence of interfering compounds that occur in the field grown plants (Lila, 2005). The advantage of this method is that it can ultimately provide a continuous, reliable source of natural products (Rao and Ravishankar, 2002). The major advantage of the cell cultures include synthesis of bioactive secondary metabolites, running in controlled environment, independently from climate and soil conditions (Karuppusamy, 2009).

\section{Production of virus free plants}

The viral diseases in plants transfer easily and lower the quality and yield of the plants. It is very difficult to treat and cure the virus infected plants therefore, plant breeders are always interested in developing and growing virus free plants. In some crops like ornamental plants, it has become possible to produce virus free plants through tissue culture at the commercial level. This is done by regenerating plants from cultured tissues derived from virus free plants, and meristems which are generally free of infection. In the elimination of the virus, the size of the meristem used in cultures play a very critical role because most of the viruses exist by establishing a gradient in plant tissues. The regeneration of virus-free plants through cultures is inversely proportional to the size of the meristem used. Chemical treatment of the media- attempts have been made to eradicate the viruses from infected plants by treating the culture medium with chemicals e.g. addition of cytokinins suppressed the multiplication of certain viruses. Among the culture techniques, meristem-tip culture is the most reliable method for virus and other pathogen elimination

\section{Protoplast fusion}

A critical requirement for crop improvement is the introduction of new genetic material into the cultivated lines of interest, whether via single genes, through genetic engineering, or multiple genes, 
through conventional hybridization or tissue culture techniques. During fertilization in angiosperms, pollen grains must reach the stigma of the host plant, germinate and produce a pollen tube. The pollen tube must penetrate the stigma and style and reach the ovule. The discharge of sperm within the female gametophyte triggers syngamy and the two sperm nuclei must then fuse with their respective partners. The egg nucleus and fusion nucleus then form a developing embryo and the nutritional endosperm, respectively. This process can be blocked at any number of stages, resulting in a functional barrier to hybridization and the blockage of gene transfer between the two plants. Prezygotic barriers to hybridization (those occurring prior to fertilization), such as the failure of pollen to germinate or poor pollen tube growth, may be overcome using in vitro fertilization. Post-zygotic barriers (occurring after fertilization), such as lack of endosperm development, may be overcome by embryo, ovule or pod culture. Where fertilization cannot be induced by in vitro treatments, protoplast fusion has been successful in producing the desired hybrids,

The technique involves the fusion of protoplasts of two different genomes followed by the selection of desired somatic hybrid cells and regeneration of hybrid plants (Evans and Bravo, 1988). Protoplast fusion provides an efficient mean of gene transfer with desired trait from one species to another and has an increasing impact on crop improvement (Brown and Thorpe, 1995). Somatic hybrids were produced by fusion of protoplasts from rice and ditch reed using electro fusion treatment for salt tolerance (Mostageer and Elshihy, 2003). In vitro fusion of protoplast opens a way of developing unique hybrid plants by overcoming the barriers of sexual incompatibility.

The technique has been applicable in horticultural industry to create new hybrids with increased fruit yield and better resistance to diseases. Successful viable hybrid plants were obtained when protoplasts from citrus were fused with other related citrinae species (Motomura et al., 1997). To resolve the problem of loss of chromosomes and decreased regeneration capacity, successful protocol has been established for the production of somatic hybrid plants by using two types of wheat protoplast as recipient and protoplast of Haynaldiavillosa as a fusion donor. It is also employed as an important gene source for wheat improvement (Liu et al., 1988).

\section{Somaclonal variation}

In nature, the genetic diversity and variability within a population are generated via recombination events. Factors such as natural selection, mutation, migration and population size influence genetic variability in different ways. In 1958 a novel, artificially produced, source of genetic variability was reported the higher plant cells cultured in vitro showed a genetic instability that was also characteristic of regenerated cells. The first observation of somaclonal variation was reported. Subsequently, the variability existing in plant tissue and cell cultures received much attention and neologisms were proposed by Larkin and Scowcroft to refer to the results of in vitro cultures of plants. The term 'somaclone' was coined to refer to plants derived from any form of cell culture, and the term 'somaclonal variation' was coined to refer to the genetic variation among such plants. The growth of plant cells in vitro and their regeneration into whole plants is an asexual process that involves only mitotic division of the cells. In this context, the occurrence of uncontrolled and random spontaneous variation when culturing plant tissue is a major problem. In vitro, the conditions of culture can be mutagenic and regenerated plants derived from organ cultures, calli, protoplasts and somatic embryos sometimes can show phenotypic and genotypic variation. Some, or all, of the somaclone may be physically different from the stock donor plants. Usually, variability occurs spontaneously and can be a result of temporary changes or permanent genetic changes in cells or tissue during in vitro culture. Temporary changes result from epigenetic or physiological effects and are non heritable and reversible . In contrast, permanent changes are heritable and often represent expression of pre-existing variation in the source plant or are a result of de novo variation. The literature to date indicates that somaclonal variation can range in scope from specific trait to the whole plant genome. Somaclonal variation provides a valuable source of genetic variation for the improvement of crops through the selection of novel variants, which may show resistance to disease, improved quality, or higher yield.

The major likely benefit of somaclonal variation in plant is improvement. Somaclonal variation leads to the creation of additional genetic variability. Characteristics for which somaclonal mutants can be enriched during in vitro culture includes resistance to disease patho toxins, herbicides and tolerance to environmental or chemical stress, as well as for increased production of secondary metabolites. Micro propagation can be carried out throughout the year independent of the seasons and plants. However, 
somaclonal variation occurs in operations which require clonal uniformity, as in the horticulture and forestry industries where tissue culture is employed for rapid propagation of elite genotypes.

\section{Micro propagation}

Micro propagation starts with the selection of plant tissues or explants from a healthy, vigorous mother plant (Murashige, 1974). Any part of the plant: leaf, apical meristem, bud and root can be used as explant. The whole process can be summarized into the following stages as shown in

\section{Production of synthetic seeds}

In synthetic seeds, the somatic embryos are encapsulated in a suitable matrix (e.g. sodium alginate), along with substances like mycorrhizae, insecticides, fungicides and herbicides. These artificial seeds can be utilized for the rapid and mass propagation of desired plant species as well as hybrid varieties. The major benefits of synthetic seeds are: They can be stored up to a year without loss of viability, easy to handle and useful as units of delivery, can be directly sown in the soil like natural seeds and do not need acclimatization in green house.

\section{Germplasm conservation}

In vitro cell and organ culture offers an alternative source for the conservation of endangered genotypes (Sengar et al, 2010). Germplasm conservation worldwide is increasingly becoming an essential activity due to the high rate of disappearance of plant species and the increased need for safeguarding the floristic patrimony of the countries (Filho et al., 2005). Tissue culture protocols can be used for preservation of vegetative tissues when the targets for conservation are clones instead of seeds, to keep the genetic background of a crop and to avoid the loss of the conserved patrimony due to natural disasters, whether biotic or abiotic stress (Tyagi et al., 2007). The plant species which do not produce seeds (sterile plants) or which have 'recalcitrant' seeds that cannot be stored for long period of time can successfully be preserved via in vitro techniques for the maintenance of gene banks.

Cryopreservation plays a vital role in the long-term in vitro conservation of essential biological material and genetic resources. It involves the storage of in vitro cells or tissues in liquid nitrogen that results incryo-injury on the exposure of tissues to physical and chemical stresses. Successful cryopreservation is often ascertained by cell and tissue survival and the ability to re grow or regenerate into complete plants or form new colonies (Harding, 2004). It is desirable to assess the genetic integrity of recovered germplasm to determine whether it is 'true-to-type' following cryopreservation (Day, 2004). The fidelity of recovered plants can be assessed at phenotypic, histological, cytological, biochemical and molecular levels, although, there are advantages and limitations of the various approaches used to assess genetic stability (Harding et al., 2005).Cryobionomics is a new approach to study genetic stability in the cryopreserved plant materials. The embryonic tissues can be cryopreserved for future use or for germplasm conservation (Corredoira et al., 2004).

\section{CONCLUSION}

Plant tissue culture have extended the range of crop species from which haploid plants have been produced as well as the efficiency resulting in large-scale haploid plant production by anther and microspore culture techniques. Specialized plant tissue culture methods have enabled the production of completely homozygous breeding lines from gametic cells in a shortened time frame compared to conventional plant breeding.

The tissue culture technique has been applicable in plant breeding; provides the means of genetic transformation, somatic embryogenesis and organogenesis, embryo rescue, haploid production, double haploid production cell suspension culture, in production of virus free plat, protoplast fusion in producing the desired hybrids, Somaclonal variation to the creation of additional genetic variability, micro propagation, production of synthetic seed and cryopreserved for future use for germplasm conservation. In general Plant tissue culture represents the most promising areas of application at present time and giving an out look into the future.

\section{REFERENCES}

[1] Ahmadi, A., Azadfar, D. and Jafari Mofidabadi, A., 2012. Study of inter-generic hybridization possibility between Salix aegyptica and Populus caspica to achieve new hybrids. International Journal of Plant Production, 4(2), pp.143-148.

[2] Bajaj, Y.P.S., 1990. In vitro production of haploids and their use in cell genetics and plant breeding. In Haploids in crop improvement I (pp. 3-44). Springer, Berlin, Heidelberg. 
[3] Basu, S.K., Datta, M., Sharma, M. and Kumar, A., 2011. Haploid production technology in wheat and some selected higher plants. Australian Journal of Crop Science, 5(9), p.1087.

[4] Bouquet, A. and Torregrosa, L., 2003.Micropropagation of the grapevine (Vitis spp.).In Micropropagation of woody trees and fruits pp. 319-352.Springer, Dordrecht.

[5] Bridgen, M.P., 1994. A review of plant embryo culture. HortScience, 29(11), pp.1243-1246.

[6] Brown, D.C.W. and Thorpe, T.A., 1995. Crop improvement through tissue culture. World Journal of Microbiology and Biotechnology, 11(4), pp.409-415.

[7] Bukovinszki, Á., Divéki, Z., Csányi, M., Palkovics, L. and Balázs, E., 2007. Engineering resistance to PVY in different potato cultivars in a marker-free transformation system using a 'shooter mutant'A. tumefaciens. Plant cell reports, 26(4), pp.459-465.

[8] Cassells, A.C. and Doyle, B.M., 2006. Pathogen and biological contamination management. In Plant cell culture protocols (pp. 35-50). Humana Press.

[9] Chatenet, M., Delage, C., Ripolles, M., Irey, M., Lockhart, B.E.L. and Rott, P., 2001. Detection of Sugarcane yellow leaf virus in quarantine and production of virus-free sugarcane by apical meristem culture. Plant Disease, 85(11), pp.1177-1180.

[10] Chattopadhyay, S., Farkya, S., Srivastava, A.K. and Bisaria, V.S., 2002. Bioprocess considerations for production of secondary metabolites by plant cell suspension cultures. Biotechnology and Bioprocess Engineering, 7(3), pp.138-149.

[11] Chauhan, H. and Khurana, P., 2011. Use of doubled haploid technology for development of stable drought tolerant bread wheat (Triticum aestivum L.) transgenics. Plant Biotechnology Journal, 9(3), pp.408-417.

[12] Chung, S.M., Vaidya, M. and Tzfira, T., 2006. Agrobacterium is not alone: gene transfer to plants by viruses and other bacteria. Trends in plant science, 11(1), pp.1-4.

[13] Cisneros, A. and Tel-Zur, N., 2010. Embryo rescue and plant regeneration following interspecific crosses in the genus Hylocereus (Cactaceae). Euphytica, 174(1), pp.73-82.

[14] Corredoira, E., San-Jose, MC., Ballester, A., Vieitez, AM., 2004. Cryopreservation of zygotic

[15] culture for the conservation and mass propagation of VrieseareitziiLeme and Costa, abromelian threatened of extinction from the Brazilian Atlantic Forest. Biodivers.Conserv. 14(8): 1799-1808.

[16] Day, J.G., 2004. Cryopreservation: fundamentals, mechanisms of damage on freezing/thawing and application in culture collections. Nova Hedwigia, pp.191-205.

[17] El-Shamy, M.M., 2011. Management of viral disease in banana using certified and virus tested plant material. African Journal of Microbiology Research, 5(32), pp.5923-5932.

[18] Ferrante, E. and Simpson, D., 2001. A review of the progression of transgenic plants used to produce plantibodies for human usage. J Young Investigators, 4(1), p.11pp.

[19] García-Gonzáles, R., Quiroz, K., Carrasco, B. and Caligari, P., 2010. Plant tissue culture: Current status, opportunities and challenges. International Journal of Agriculture and Natural Resources, 37(3), pp.5-30.

[20] George, E.F., 1993. Plant propagation by tissue culture. Part 1: The technology No. Ed. 2. Exegetics limited.

[21] Guerra, M.P. and Handro, W., 1988. Somatic embryogenesis and plant regeneration in embryo cultures of Euterpe edulis Mart.(Palmae). Plant Cell Reports, 7(7), pp.550-552.

[22] Haberlandt, G., 1902. Sitzungsber. Akad. Wiss. Wien, Math. Natwiss. K, 1, pp.69-91.

[23] Han, G.Y., Wang, X.F., Zhang, G.Y. and Ma, Z.Y., 2009. Somatic embryogenesis and plant regeneration of recalcitrant cottons (Gossypium hirsutum). African Journal of Biotechnology, 8(3).

[24] Harding, K., 2004. Genetic integrity of cryopreserved plant cells: a review. CryoLetters, 25(1), pp.3-22.

[25] Harding, K., Johnston, J. and Benson, E.E., 2005. Plant and algal cell cryopreservation: issues in genetic integrity, concepts in 'Cryobionomics' and current European applications. Contributing to a sustainable future, Proceedings of the Australian branch of the IAPTC and B, Perth, Western Australia.

[26] Hellwig, S., Drossard, J., Twyman, R.M. and Fischer, R., 2004. Plant cell cultures for the production of recombinant proteins. Nature biotechnology, 22(11), pp.1415-1422.

[27] Hinchee, M.A.W., Corbin, D.R., Armstrong, C.L., Fry, J.E., Sato, S.S., DeBoer, D.L., Petersen, W.L., Armstrong, T.A., Connor-Ward, D.V., Layton, J.G. and Horsch, R.B., 1994. Plant transformation. In Plant cell and tissue culture (pp. 231-270). Springer, Dordrecht.

[28] Holeman, D.J., 2009. Simple Embryo Culture for Plant Breeders A manual of technique for the extraction and in-vitro germination of mature plant embryos with emphasis on the rose First Edition October 3, 2009.

[29] Husain, M.K. and Anis, M., 2009. Rapid in vitro multiplication of Melia azedarach L.(a multipurpose woody tree). Acta Physiologiae Plantarum, 31(4), pp.765-772. 
[30] Hussain, A., Naz, S., Nazir, H. and Shinwari, Z.K., 2011. Tissue culture of black pepper (Piper nigrum L.) in Pakistan. Pak. J. Bot, 43(2), pp.1069-1078.

[31] Hussain, A., Qarshi, I.A., Nazir, H. and Ullah, I., 2012. Plant tissue culture: current status and opportunities. Recent advances in plant in vitro culture, pp.1-28.

[32] Idowu, P.E., Ibitoye, D.O. and Ademoyegun, O.T., 2009. Tissue culture as a plant production technique for horticultural crops. African Journal of Biotechnology, 8(16).

[33] James, C., 2008. Global Status of Commercialized Biotech/GM Crops. ISAAA Brief No. 37. International Service for the Acquisition of Agri-biotech Applications.

[34] Jayasankar, S., Gray, D.J. and Litz, R.E., 1999. High-efficiency somatic embryogenesis and plant regeneration from suspension cultures of grapevine. Plant Cell Reports, 18(7), pp.533-537.

[35] Karuppusamy, S., 2009.A review on trends in production of secondary metabolites from higher plants by in vitro tissue, organ and cell cultures.Journal of Medicinal Plants Research, 3(13), pp.1222-1239.

[36] Khan, RS., Alam, SS., Munir, I., Azadi, P., Nakamura, I., Mii, M., 2011. Botrytis cinerearesistant markerfree Petunia hybridaproduced using the MAT vector system. Plant Cell Tissue Organ Cult. 106: 11-20.

[37] Lila, MA., 2005. Valuable secondary products from in vitro culture. In: Trigiano RN, Gray DJ (eds) Plant development and biotechnology. CRC Press LLC, pp 285-289

[38] Liu, D.J., 1988. Transfer of Haynaldia villosa chromosomes into Triticum aestivum. In Proc. 7th Int. Wheat Genet. Symp. pp. 355-361. IPSR.

[39] Marino, G. and Battistini, S., 1989, May. Leaf-callus growth, shoot regeneration and somaclonal variation in actinidia deliciosa: effect of media $\mathrm{pH}$. In I International Symposium on In Vitro Culture and Horticultural Breeding 280 pp. 37-44.

[40] Maynard, C., Xing, Z., Bickel, S. and Powell, W., 1998. Using genetic engineering to help save the American chestnut: a progress report. Journal of the American Chestnut Foundation, 12, pp.40-56.

[41] Misra, M. and Misra, A.N., 1993, May. Genetic transformation of grass pea. In DAE Symposium on Photosynth. \& Plant Molecular Biology, BRNS/DAE, Govt. of India (pp. 246-251).

[42] Miyajima, D., 2006. Ovules that failed to form seeds in zinnia (Zinnia violacea Cav.). Scientia horticulturae, 107(2), pp.176-182.

[43] Mohan, N., Nikdad, S. and Singh, G., 2011.Studies on seed germination and embryo culture of Jatropha curcas L. under in vitro conditions.Research Article, Biotechnol, Bioinf, Bioeng, 1(2), pp.187-194.

[44] Morrison, R.A. and Evans, D.A., 1988. Haploid plants from tissue culture: new plant varieties in a shortened time frame. Bio/technology, 6(6), pp.684-690.

[45] Mostageer, A. and Elshihy, O.M., 2003. Establishment of a salt tolerant somatic hybrid through protoplast fusion between rice and ditch reed. Arab J Biotech, 6(1), pp.01-12.

[46] Motomural, T., Hidaka, T., Akihamal, T., Katagi, S., Berhow, M.A., Moriguchi, T. and Omura, M., 1997. Protoplast fusion for production of hybrid plants between Citrus and its related genera. Journal of the Japanese Society for Horticultural Science, 65(4), pp.685-692.

[47] Murashige, T. and Skoog, F., 1962. A revised medium for rapid growth and bio assays with tobacco tissue cultures. Physiologia plantarum, 15(3), pp.473-497.

[48] Murashige, T., 1974. Plant propagation through tissue cultures. Annual review of plant physiology, 25(1), pp.135-166.

[49] Navarro Mastache, L.C., 2004, November. Large scale commercial micropropagation in Mexico. The experience of Agromod, SA de CV. In II International Symposium on Acclimatization and Establishment of Micropropagated Plants 748 (pp. 91-94).

[50] Okere, A.U. and Adegeye, A., 2011. In vitro propagation of an endangered medicinal timber species Khayagrandifoliola C. Dc. African Journal of Biotechnology, 10(17), pp.3335-3339.

[51] Pareek, L.K. and Pareek, L.K., 2006. Trends in plant tissue culture and biotechnology.Agrobios.

[52] Park, Y.S., Barrett, J.D. and Bonga, J.M., 1998. Application of somatic embryogenesis in high-value clonal forestry: deployment, genetic control, and stability of cryopreserved clones. In Vitro Cellular \& Developmental Biology-Plant, 34(3), pp.231-239.

[53] Rao, S.R. and Ravishankar, G.A., 2002. Plant cell cultures: chemical factories of secondary metabolites. Biotechnology advances, 20(2), pp.101-153.

[54] Rao, S.R. and Ravishankar, G.A., 2002. Plant cell cultures: chemical factories of secondary metabolites. Biotechnology advances, 20(2), pp.101-153.

[55] RechFilho, A., Dal Vesco, L.L., Nodari, R.O., Lischka, R.W., Müller, C.V. and Guerra, M.P., 2005. Tissue culture for the conservation and mass propagation of VrieseareitziiLeme and Costa, a bromeliad threatened of extinction from the Brazilian Atlantic Forest. Biodiversity \& Conservation, 14(8), pp.1799-1808. 
[56] Sage, T.L., Strumas, F., Cole, W.W., Barret, S., 2010. "Embryo rescue and plant regeneration following interspecific crosses in the genus Hylocereus (Cactaceae)". Euphytica 174: 73-82.

[57] Sasson, A., 1993. Biotechnologies in Developing Countries: Presmtami Future, Vol. 1. Paris: United Nations Educational, Scientific and Cultural Organization.

[58] Sengar, R.S., Chaudhary, R. and Tyagi, S.K., 2010. Present status and scope of floriculture developed through different biological tools. Res J. of Agri. Sci, 1(4), pp.306-314.

[59] Sinclair, T.R., Purcell, L.C. and Sneller, C.H., 2004. Crop transformation and the challenge to increase yield potential.Trends in plant science, 9(2), pp.70-75.

[60] Singh, R.B., 1989. Current status and future prospects of plant biotechnologies in developing countries in Asia. In Plant biotechnologies for developing countries: proceedings of an international symposium organized jointly by the Technical Centre for Agricultural and Rural Co-operation and the FAO and held in Luxembourg, 26-30 June 1989. Ede, Netherlands: CTA, 1989.

[61] Skoog, F., Miller, CO., 1957. Chemical regulation of growth and organ formation in plant

[62] somatic embryogenesis and shoot organogenesis in Rosa. Plant Physiol. 159: 313-319.

[63] Sudhersan, C., Manuel, S.J. and Al-Sabah, L., 2008. Haploid plant production from pollen grains of Sturt's Desert Pea via Somatic Embryogenesis. American-Eurasian J Sci Res, 3, pp.44-47.

[64] Thorpe, T.A., 2007. History of plant tissue culture. Molecular biotechnology, 37(2), pp.169-180.

[65] Tilkat, E., Onay, A., Yıldırım, H. and Ayaz, E., 2009. Direct plant regeneration from mature leaf explants of pistachio, Pistaciavera L. Scientia Horticulturae, 121(3), pp.361-365.

[66] Toriyama, K., Hinata, K. and Kameya, T., 1987. Production of somatic hybrid plants, 'Brassicomoricandia', through protoplast fusion between Moricandiaarvensis and Brassica oleracea. Plant Science, 48(2), pp.123-128.

[67] Trigiano, R.N. and Gray, D.J. eds., 2004. Plant development and biotechnology. CRC press.

[68] Tyagi, R.K., Agrawal, A., Mahalakshmi, C., Hussain, Z. and Tyagi, H., 2007. Low-cost media for in vitro conservation of turmeric (Curcuma longa L.) and genetic stability assessment using RAPD markers.In Vitro Cellular \& Developmental Biology-Plant, 43(1), pp.51-58.

[69] Xiangqian, X., Krasnyanski, S.F. and Korban, S.S., 2002. Somatic embryogenesis, secondary somatic embryogenesis, and shoot organogenesis in Rosa. Journal of plant physiology, 159(3), pp.313-319.

[70] Yeung, E.C., EC, Y., TA, T. and CJ, J., 1981. In vitro fertilization and embryo culture in plant tissue culture: Methods and Applications in Agriculture, New York: 253-271.

Citation: Sisay Argaye, (2021). "Development and the Role of Tissue Culture in Plant Breeding: A review ", International Journal of Research Studies in Agricultural Sciences (IJRSAS), 7(5), pp. 27-36 DOI: http://dx.doi.org/10.20431/2454-6224.0705004

Copyright: (C) 2021 Authors. This is an open-access article distributed under the terms of the Creative Commons Attribution License, which permits unrestricted use, distribution, and reproduction in any medium, provided the original author and source are credited. 